\title{
EUROPEAN UNION DIGITAL SINGLE MARKET - GET CONNECTED OR STILL A VISION FROM THE SLOVAK REPUBLIC PERSPECTIVE?
}

\author{
Silvia Ručinská ${ }^{1}$ and Miroslav Fečko²
}

\begin{abstract}
European Union Internal Market has become a key element of the European integration and of a citizens' daily life. Some of the European Union Internal Market's components are well established and functioning, others have still to struggle with existing barriers. New information and communication technologies and the digitalisation challenged the European Union Internal Market and the European Union Member States to move into the digital era. European Union Member States are now facing the need to adapt the four economic freedoms as a crucial part of the European Union Internal Market to a digital freedom. The aim of the article is to analyse the current state of play of the European Union Digital Single Market and to identify most common and urgent existing obstacles of the European Union Digital Single Market from the perspective of the Slovak Republic.
\end{abstract}

Key words: European Union, Internal Market, Digital Single Market, Slovak Republic, Barriers.

\section{Introduction}

The EU Internal Market as a territory of free movement of goods, services, capital and person is still developing and can be considered as a gradual process, which is characterized by its complexity (Arnold and Wörgötter, 2011; Howart and Sadeh, 2010). The ability to travel, work, buy or sell across the EU Member States has become an integral part of the EU citizen's daily life, which is hard to imagine not having it. The EU Internal Market is also essential not only for the individuals or businesses, but also for the entire EU economy and EU Member State's economies. Rueda-Cantuche et al. (2013) highlighted that the EU Internal Market helps to create jobs through the exporting companies, what bring employment opportunities not only in the exporting country but also in the entire EU Internal Market. Egan and Guimaraes (2012) described the EU Internal Market as the key element of EU's integration and as a precondition for creating jobs and employment across the EU. Juncker (2014) when introducing the European Commission's political guidelines and when identifying the completion of the EU Internal Market as one of the priorities of the European Commission under his presidency, has stressed out the EU Internal Market as the biggest asset of Europe.

Even though the EU Internal Market is far from completion, because of many different barriers existing in relation to the entire EU Internal Market and within each of the EU Internal Market's economic freedoms ${ }^{3}$, the EU Internal Market has to update itself to new opportunities and

\footnotetext{
${ }^{1}$ Pavol Jozef Šafárik University in Košice, Faculty of Public Administration, silvia.rucinska@upjs.sk

${ }^{2}$ Pavol Jozef Šafárik University in Košice, Faculty of Public Administration, miroslav.fecko@upjs.sk

${ }^{3}$ For more about the barriers to the entire EU Internal Market and to the free movement of goods, services, capital and person see for example: Guimarăes and Egan (2014); Egan and Guimarăes (2012); Terták (2010); Hafner, Robin and Hoorens (2014); Jacobsson (2013); Pelkmans and Mustilli (2014); Robin-Olivier (2012); van Riemsdijk (2013).
} 
challenges regarding the use of information and communication technologies (ICT). ICT are now present in all sectors of the economy (European Commission, 2015b), they interfere with social and economic activities (European Commission, 2013) and they are a fundamental part of people's life, companies' activities and also of governments. Digital economy helps the markets to grow, fosters the quality of services provided, creates additional sources for employment and economic growth (European Commission, 2015b; Szczepański, 2015). Between 2001 and 2011 the ICT accounted for more than third of the GDP growth and for almost third of the labour productivity growth in the EU and for more than a half of the GDP and labour productivity growth in the USA (European Commission, 2015a; European Commission, 2013).

According to Copenhagen Economics (2010), the Digital Single Market can be considered as a next step of European integration, following the previous milestones represented by the EU Internal Market, European Monetary Union and implementation of the Services Directive. The importance of the Digital Single Market was highlighted by the European Parliament (2015) when concluding, that the potential benefits from completing the Digital Single Market would reach 415 billion euro per year, in the area of e-commerce, e-procurement, single European payments, e-invoicing, cloud computing, online and alternative dispute resolution systems. Paczynski (2014) summed up the positive impacts in the entire EU by 2020 , in GDP expenditure measure $(0.39 \%$ effect $)$, consumption $(0.37 \%$ effect), Investment $(0.90 \%$ effect), Exports $(0.26 \%$ effect $)$, Imports $(0.31 \%$ effect) and Employment $(0.10 \%$ effect), which would be achievable because of the Digital Single Market deficiencies' elimination. Lorenzani and Varga (2014) concluded, that the Digital Single Market will bring in long run a GDP impact of $1 \%$ in the EU27 average with a further potential of an initial 3.14\% GDP impact also in the EU27 average.

In this paper we are repeatedly using the terms internal market and single market. We don't consider these terms as synonymous. Some authors tend to use only the term internal market, others do prefer the term single market and a synonymous usage can be also find in the literature. But our intention won't be to provide a terminological explanation of the different meanings and usages in this paper. We do consider as important to highlight this and to clarify, that we prefer to use the term EU Internal Market, as it is also applied in the primary EU law. Regarding the Digital Single Market, we will be using the term single market, because it was as such defined in the official EU declarations, agendas, priorities, etc.

The aim of this paper is to analyse the current state of play of the Digital Single Market in the EU and to identify the most common and urgent existing barriers to the Digital Single Market with a specific view from the perspective of the Slovak Republic. The paper is structured into two main parts. The first part of the paper will analyse the entire Digital Single Market, its importance and impact to the economy of the EU and its relevance as an EU political priority. In addition to that, the most common barriers will be identified, which hinder the completion of the Digital Single Market and the use of its potential. Our intention won't be to identify barriers to the entire EU Internal Market though. We will focus only on barriers occurring in the online space, or in relation to the use of Digital Single Market's components. The second main part will focus on the Slovak Republic's experiences in terms of building the Digital Single Market and tackling with existing obstacles.

\section{Digital Single Market and barriers to the Digital Single Market}

The Digital Single Market can be understood as a market ensuring the free movement of goods, services, capital and person without barriers hindering the use of digital technologies and online 
services, allowing cross border online purchase of goods and services, bringing benefits to consumers and businesses, protecting consumers and personal data and thus fostering economic growth, jobs and innovation across the EU and it's Member States (European Commission, 2015b; Copenhagen Economics, 2010).

A functioning Digital Single Market and in this regard a better use of the potential what the digital market has, have become one of the ten priorities of the European Commission under the presidency of J.C. Juncker. A connected Digital Single Market was introduced as a horizontal political priority important for every sector of the economy, including the public sector (Juncker, 2014). The Digital Single Market as a theme of high priority wasn't any knew though. According to Szczepański (2015) EU's efforts aimed at the components of the Digital Single Market have started in mid 1990s. Copenhagen Economics published in 2010 a study regarding economic impact of the Digital Single Market, which highlighted the necessity of tackling deficiencies of the Digital Single Market. The Study summarized, that some steps have been done in the past, but nevertheless the Digital Single Market can't be considered as completed and its potential remains untapped, even though it brings considerable benefits for individuals, companies but also for the public sector (Copenhagen Economics, 2010). Polanski (2015) has also stressed out, that the current situation in the EU can't be considered as a completed Digital Single Market, but rather as 28 individual digital markets.

Building on the Digital Single Market as of one of the Commission's priorities, the European Commission adopted the Digital Single Market Strategy in 2015. The Digital Single Market Strategy was introduced based on three main pillars, Better access for consumers and businesses to online goods and services across Europe; Creating the right conditions for digital networks and services to flourish; Maximising the growth potential of our European Digital Economy (European Commission, 2015b). Even though in 2016, 85\% of all EU households have had internet access at home (Eurostat, 2017c), 82\% of individuals aged from 16 to 74 in the EU have used internet in last 3 months and only 14\% of individuals have never used internet (Eurostat, 2017b), only 18\% of individuals in the EU have used internet for ordering goods or services from other EU Member States (Eurostat, 2017a). To accomplish the Digital Single Market Strategy, the European Commission (2017a) have set the update of e-commerce rules, review of consumer protection rules, affordability of parcel delivery, ending of an unjustified geo-blocking, antitrust competition inquiry, modernisation of copyright rules, review of online cross border distribution of television and radio programmes and VAT burdens as the main goals for a better access for consumers and businesses to online goods. To improve the digital networks and services, the European Commission (2017c) identified telecom rules, audiovisual media rules, online platforms and data security as the most urgent problems to be dealt with. Finally in relation to the third pillar focusing on the growth potential and benefits of the European Digital Economy, the attention should be aimed on to free flow of data, standards and interoperability and on the inclusive digital economy helping the citizens to take advantage from it (European Commission, 2017b).

Despite the importance of the Digital Single Market and of the past and current strategies to considerably progress in its completion, barriers hindering this completion still exist. The European Commission (2013) summarized overall barriers to ICT, which can be considered as limits to the importance and impact what the ICT have. These ICT barriers were presented in four main groups, introducing their character and type of obstacle they represent. Educational barriers have been analysed in relation to the lack of needed skills, incompatibility of education and practice needs, underestimation of the importance and of the potential which the ICT have. Organisational and cultural barriers were identified as connected to a lack of entrepreneurship, lack of exploitation of 
the ICT's potential and as other entrepreneurship type deficiencies. Policy barriers were elaborated reflecting the everlasting legal and regulatory fragmentation within the EU Member States, lack of flexibility in labour market related activities and infrastructure orientation rather than demand development. Final group of barrier have been more of a subjective nature, represented by social barriers and different kinds of hesitations in adopting and using new ICT.

A Digital Single Market should create more opportunities for individuals and business, especially in relation to employment and restrict existing barriers. These barriers can be of different nature, as for example an unequal treatment in delivery costs and delivery conditions, geo-blocking, lack of digital skills, lack of digital technologies and fragmented national regulations (European Commission, 2016a; Bassot and Hiller, 2016). European Parliament (2015) has also pointed out the existence of barriers hindering the completion of the Digital Single Market, however with an additional statement, that it is unlikely to remove all existing barriers, because of the overall complexity of the barriers removing process. The most urgent obstacles identified by the Mapping the Cost of Non-Europe 2014-2019 study (European Parliament, 2015) were related to e-privacy, epayments, VAT payments, consumer protection and dispute resolution, data protection and geoblocking. Existing subjective barriers, which are related to trust issues of the consumers in the online space are characterized by the tendency of the consumers to avoid buying across borders and to prefer to shop nationally, mainly because of cultural, language or brand recognition influences (European Commission, 2015a).

According to the Flash Eurobarometer 413, the companies which sell online to the EU Member States, but also the companies which don't sell online, including such ones which are willing to try in the future, encounter difficulties which are most commonly cost related. These difficulties represent obstacles related to high delivery costs, costly guarantees and returns, resolving complains and disputes but also unfamiliarity with existing rules in other EU Member States (European Commission, 2015c).

Barriers to the Digital Single Market are of different nature. The main occurring barriers are educational, organisational, policy, legal, regulatory, cultural, social, language deficiencies and restrictions. Some of these obstacles can the EU Member States tackle, by a more consistent adoption of needed rules and by removing considerably high regulatory fragmentation. Other barriers are of a more subjective nature and that's why they can be seen as persisting barriers to the Digital Single Market. Even if not all barriers could be eliminated, this shouldn't hinder the EU Member States of trying it, because the potential benefits for the overall EU economy and for the citizen's life could be significant.

\section{Digital Slovak Republic - state of play and restrictions}

As a reaction to the activities of the European Commission in the field of Digital Single Market, but also responding to the changes in the overall society regarding the digital age, Slovak Republic is trying to harmonize and coordinate its activities. According to the Legislative Act No. 575/2001 about the organization of government's activities and organization of the central state administration, a special office called The Office of the Deputy Prime Minister of the Slovak Republic for Investments and Informatisation was created. Following the Statute of the Office of the Deputy Prime Minister of the Slovak Republic for Investments and Informatisation (2017), its main goal is to contribute to a common state policy in the field of using EU funds and regarding informatisation and investments. 
To procced even more in the digitalization of the Slovak Republic and to enable a coordinating approach, Peter Pellegrini, as the Deputy Prime Minister for Investments and Informatisation, proposed the Action plan: Single Digital Market - opportunity for Slovakia (Action Plan). The Action Plan (2017) refers to the European Commission's priorities in the Digital Single Market and to the three main pillars of the Digital Single Market Strategy. The Action Plan (2017) highlights the importance of the Digital Single Market when stating, that its successful implementation will affect the position of the Slovak Republic in the global competition.

To proceed in the next transformation and in the development of the digital economy, the Action Plan (2017) projects the change of rules to simplify and to improve the people's life, to create appropriate conditions for entrepreneurs and for sustainable jobs and to modernize the functioning of the public administration. Five priority themes have been proposed to fulfil the expected outcomes: creation of a data economy, digitalization of public services for an inclusive information society (e-society), online platforms to support digital economy and smart industry, modern tools for the digital creative industry's development, education and digital skills for the modern age. The strength of the Action Plan is, that in each of the priority themes it refers to other existing plans and documents existing in the Slovak Republic and to EU's initiatives. Therefore, it can contribute to the orientation in such complex and interlinked theme, as the digitalization certainly is. Also of a major importance is an elaboration of the priority themes into specific tasks which should be dealt with, with the addition of time schedules in each task.

A concept of political, professional and participatory coordination is also a part of the Action Plan (2017). When assessing the real contribution of the Action Plan to fulfil all the specified tasks and priorities, concerns may arise, especially when considering the fragmentation of competences in this field in the Slovak Republic. Altogether 15 different ministries and official state authorities, but also other subjects are involved in fulfilling the Action Plan's tasks. Thus, the success relies on the cooperation of the Deputy Prime Minister for Investments and Informatisation; Government Office; Plenipotentiary of the Government of the Slovak Republic for the Development of Civil Society; Ministry of Economy; Ministry of Finance; Ministry of Interior; Ministry of Labour, Social Affairs and Family; Ministry of Transport and Construction; Ministry of Justice; Ministry of Culture; Ministry of Education, Science, Research and Sport; Office for Personal Data Protection; National Security Authority; Office for Public Procurement; Industrial property Office; supervision offices but also of universities. Even though the number of responsible authorities in each of the particular tasks isn't higher than four, the main role what the Action Plan is aiming for, the coordinating role, can be one of the weaknesses because of responsibility's fragmentation. Such responsibility's mixture combined with an unclear financing needs and covering expenses of each task, can be considered as highly risky and threatening a successful implementation.

The Action Plan has been interdepartmental reviewed in early February 2017 and the next steps of its adopting are going to be focused onto consider, accept or reject the comments of state government authorities but also from civil society and third sector subjects. According to the Action Plan (2017) altogether 174 comments, 95 of them marked as substantial, from 20 different subjects and from the public, have been raised during the interdepartmental review process. By way of example, the Ministry of Finance, but also the Ministry of Interior and Ministry of Culture have claimed the missing financial requirements for implementation and sustainability; Ministry of Culture requested to withdraw the entire material, because as it is a horizontal policy, it should be formulated from beginning in close cooperation of all relevant subjects; The American Chamber of Commerce in Slovakia proposed addition of new tasks of the Action Plan aimed at the important safety and security issues; The National Union of Employers highlighted the insufficient 
communication with employers regarding the elaboration of this Action Plan; Slovak Association for Branded Products identified the missing risk assessment for businesses as one of the weaknesses of the Action Plan; and other comments of concrete subjects claiming the absence of competences in particular field or in the opposite refusing to take responsibilities in specific area dealt with by the Action Plan. For the real assessment, the final text should be analysed though. But the overall intention of adopting a strategic document can be considered as needed.

\section{Conclusion}

The EU Internal Market can be considered as one of the EU's most important achievements. Free movement of goods, services, capital and person have come a long way, since the initial steps when introducing the Single European Act and when regularly reformulating actions of the EU regarding the four economic freedoms. Despite the achievements, barriers to EU Internal Market and to the free movement of goods, services, capital and person persist up until present. The digital era and ICT development, have brought opportunities to grow the economies worldwide. In this regard, however, new challenges have also appeared, what the EU Internal Market is trying to deal with by creating the Digital Single Market. The Digital Single Market has brought benefits to the economy, businesses and citizens, but its potential is far from reached. Barriers to the Digital Single Market are of educational, legal, regulatory, organisational, policy, social, cultural and language nature. Next research could be focused on, whether the barriers to the Digital Single Market exist because of the existence of the barriers to the EU Internal Market, or whether they aren't interrelated. Considering the Slovak Republic and its achievements in the Digital Single Market, the fragmentation in competences and the need to cover expenses regarding digital market's priorities and tasks, are of potential high importance for the future to be dealt with.

\section{References}

[1] Action plan: Single Digital Market - opportunity for Slovakia. 2017. Legislative process number LP/2017/53.

[2] ARNOLD, J. M. and WÖRGÖTTER, A.: Structural reforms and the benefits of the enlarged EU internal market: still much to be gained. In: Applied Economics Letters. Vol. 18, Issue 13, 2011, pp. 1231-1235.

[3] BASSOT, É. and HILLER, W.: The Juncker Commission's ten priorities. State of play in mid2016. European Parliament: European Parliamentary Research Service, 2016.

[4] COPENHAGEN ECONOMICS, The Economic Impact of a European Digital Single Market, 2010. Available at «http://www.epc.eu/dsm/2/Study_by_Copenhagen.pdf» Accessed 16 January 2017.

[5] EGAN, M. and GUIMARAES, H.: Compliance in the single market. In: Business \& Politics. Vol. 14, Issue 4, 2012, pp. 1-28.

[6] EUROPEAN COMMISSION, Unlocking the ICT growth potential in Europe: Enabling people and businesses. Using Scenarios to Build a New Narrative for the Role of ICT in Growth in Europe. Luxembourg, Publications Office of the European Union, 2013. 
[7] EUROPEAN COMMISSION, 2015a. Commission Staff Working Document. A Digital Single Market Strategy for Europe - Analysis and Evidence. Accompanying the document Communication from the Commission to the European Parliament, the Council, the European Economic and Social Committee and the Committee of the Regions A Digital Single Market Strategy for Europe. SWD(2015) 100 final.

[8] EUROPEAN COMMISSION, 2015b. Communication from the Commission to the European Parliament, the Council, the European Economic and Social Committee and the Committee of the Regions. A Digital Single Market Strategy for Europe. COM(2015) 192 final.

[9] EUROPEAN COMMISSION, 2015c. Flash Eurobarometer 413. Companies engaged in online activities. Available at «http://ec.europa.eu/public_opinion/flash/fl_413_en.pdf» Accessed 23 January 2017.

[10] EUROPEAN COMMISSION, 2016a. A digital single market in Europe. Bringing down barriers to unlock online opportunities. Luxembourg: Publications Office of the European Union.

[11] EUROPEAN COMMISSION, 2017a. Better access for consumers and business to online goods. Available at «https://ec.europa.eu/digital-single-market/node/78515» Accessed 20 January 2017.

[12] EUROPEAN COMMISSION, 2017b. Economy \& Society. Available at «https://ec.europa.eu/digital-single-market/node/78517» Accessed 20 January 2017.

[13] EUROPEAN COMMISSION, 2017c. Right environment for digital networks and services. Available at «https://ec.europa.eu/digital-single-market/node/78516» Accessed 20 January 2017.

[14] EUROPEAN PARLIAMENT, Mapping the Cost of Non-Europe, 2014 -19. Brussels: European Added Value Unit, Directorate for Impact Assessment and European Added Value, Directorate-General for Parliamentary Research Services (EPRS), European Parliament, 2015.

[15] EUROSTAT, 2017a. Individuals using the internet for ordering goods or services from other EU countries. Available at «http://ec.europa.eu/eurostat/tgm/table.do?tab=table\&init= 1\&language $=$ en\&pcode=tin00003\&plugin=1» Accessed 16 January 2017.

[16] EUROSTAT, 2017b. Internet use by individuals. Available at «http://ec.europa.eu/eurostat/tgm/refreshTableAction.do?tab=table\&plugin=1\&pcode=tin000 28\&language=en» Accessed 16 January 2017.

[17] EUROSTAT, 2017c. Level of internet access - households. Available at «http://ec.europa.eu/eurostat/tgm/table.do?tab=table\&init=1\&language=en\&pcode=tin00134 \&plugin=1» Accessed 16 January 2017.

[18] GUIMARAES, H. and EGAN, M.: Barriers to Business in the Single Market, 2014. Available at http://ssrn.com/abstract=2399098 Accessed 20 December 2016. 
[19] HAFNER, M., ROBIN, E. and HOORENS, S.: The Cost of Non-Europe in the Single Market. I - Free Movement of Goods. Brussels: European Union, 2014.

[20] HOWARTH, D. and SADEH, T.: The ever incomplete single market: differentiation and the evolving frontier of integration. In: Journal of European Public Policy. Vol. 17, Issue 7, 2010, pp. 922-935.

[21] JACOBSSON, J.: Liberalisation of Service Mobility in the EU's International Trade Agreements: As External as it Gets. European Journal of Migration \& Law, Vol. 15, No. 3, 2013, pp. 245-261.

[22] JUNCKER, J.-C.: A New Start for Europe: My Agenda for Jobs, Growth, Fairness and Democratic Change. Political Guidelines for the next European Commission. Opening Statement in the European Parliament Plenary Session, 2014. Available at «http://ec.europa.eu/priorities/sites/beta-political/files/juncker-political-guidelines_en.pdf» Accessed 9 January 2017.

[23] Legislative Act No. 575/2001 about the organization of government's activities and organization of the central state administration.

[24] LORENZANI, D. and VARGA, J.: The Economic Impact of Digital Structural Reforms. European Commission Economic Papers, No 529, 2014.

[25] PACZYNSKI, W.: The Cost of Non-Europe in the Single Market. III. Digital Single Market. European Parliament. European Parliamentary Research Service. European Added Value Unit, 2014.

[26] PELKMANS, J. and MUSTILLI, F.: The Cost of Non-Europe in the Single Market. II The Single Market for Services. European Union, Brussels, 2014.

[27] POLANSKI, P. P.: Towards the single digital market for e-identification and trust services. Computer Law \& Security Review, Vol. 31, No. 6, 2015, pp. 773-781.

[28] ROBIN-OLIVIER, S.: Bargaining in the shadow of free movement of capital. European Review of Contract Law, Vol. 8, No. 2, 2012, pp. 167-183.

[29] RUEDA-CANTUCHE, J. M. et al.: The Single Market as an Engine for Employment through External Trade. In: Journal of Common Market Studies. Vol. 51, Issue 5, 2013, pp. 931-947.

[30] Statute of the The Office of the Deputy Prime Minister of the Slovak Republic for Investments and Informatisation, 2017. Available at «https://www.vicepremier.gov.sk/ index.php/o-urade/statut-uradu/index.html» Accessed 27 January 2017.

[31] SZCZEPAŃSKI, M.: A Digital Single Market Strategy for Europe. Tracking European Commission priority initiatives in 2015 - Number 3. European Parliamentary Research Service, 2015. Available at http://www.europarl.europa.eu/RegData/etudes/ BRIE/2015/568325/EPRS_BRI(2015)568325_EN.pdf Accessed 23 January 2017. 
[32] TERTÁK, E.: The EU internal market for occupational pensions: Making further progress. Pensions: An International Journal, Vol. 15, No. 2, 2010, pp. 140-147.

[33] VAN RIEMSDIJK, M.: Obstacles to the Free Movement of Professionals: Mutual Recognition of Professional Qualifications in the European Union. European Journal of Migration \& Law, Vol. 15, No. 1, 2013, pp. 47-68. 